\title{
Optimization of lipophilic compounds in tortillas from native pigmented maize obtained from flours by the lime cooking extrusion process
}

\author{
Optimización de compuestos lipofílicos en tortillas de maíz pigmentado nativo obtenidas a partir de \\ harinas por el proceso de extrusión cocción alcalina
}

\begin{abstract}
Saraid Mora-Rochín 1,2, Mariela Menchaca-Armenta2 ${ }^{2}$ Ada K. Milán-Noris', Janet Alejandra Gutierrez-Uribe ${ }^{3}$, Edith 0. Cuevas-Rodriguez ${ }^{1,2}$, Cuauhtémoc Reyes-Moreno ${ }^{1,2}$, Jorge Milán-Carrillo ${ }^{1,2 *}$

Programa de Posgrado Integral en Biotecnología, Facultad de Ciencias Químico Biológicas, Universidad Autónoma de Sinaloa, Culiacán, Sinaloa, C.P. 80000, México.

2 Maestría en Ciencia y Tecnología de Alimentos, Facultad de Ciencias Químico Biológicas, Universidad Autónoma de Sinaloa, Culiacán, Sinaloa, C.P. 80000, México.

Departamento de Biotecnología e Ingeniería de Alimentos, Instituto Tecnológico y de Estudios Superiores de MonterreyCampus Monterrey, Av. Eugenio Garza Sada 2501 Sur, Monterrey, Nuevo León, C.P. 64849, México.
\end{abstract}

\section{ABSTRACT}

The lime-cooking extrusion process depicts a technological alternative; however, it implies suitable combinations of the main extrusion process factors to obtain good quality flour and tortillas. Multi-response optimization by response surface methodology (RSM) was used as a tool to optimize the native pigmented maize lime-cooking extrusion process to obtain flours to develop tortillas with high lipophilic compounds. The effects of extrusion temperature (ET, 65-150 $\left.{ }^{\circ} \mathrm{C}\right)$ and screw speed (SS, 78-240 rpm) were investigated. The best extruded blue maize tortillas were selected over response variables: Linoleic acid (LA), Oleic acid (OA), Campesterol (CP), Stigmasterol (SP), and $\beta$-sitosterol $(\beta S P)$, where the quadratic predictive developed models were adequate and reproducible inside the specified array of process factors. Appling desirability function, the optimum lime-cooking extrusion conditions to develop extruded blue maize tortillas correspond to ET $\left(119^{\circ} \mathrm{C}\right)$, SS $(79 \mathrm{rpm})$, with a global desirability value $(D=0.906)$. Values response variables obtained from the predictive models were compared from experimental tests, and a close agreement between both values was observed. Hence, RSM is still convenient for optimization, particularly once used in a mixture with other procedures.

Keywords: Native maize, lime cooking extrusion, optimization, desirability function, response surface methodology

\section{RESUMEN}

El proceso de cocción-alcalina por extrusión, representa una alternativa tecnológica, sin embargo, implica combinaciones adecuadas de los principales factores del proceso de extrusión para obtener harina y tortillas de buena calidad. Optimización de respuesta múltiple por metodología de superficie de respuesta (MSR) se aplicó como herramienta para optimizar el proceso de cocción-alcalina por extrusión sobre maíz pigmentado nativo para obtener harinas para elaborar tortillas con compuestos lipofílicos altos. El efecto de temperatura de extrusión $\left(\mathrm{TE}, 65-150^{\circ} \mathrm{C}\right.$ ) y velocidad de tornillo (VT, 78-240 rpm) fueron investigadas. Las mejores

*Autor para correspondencia: Jorge Milán Carrillo

Correo electrónico:jmilanc@uas.edu.mx

Recibido: 16 de noviembre de 2020

Aceptado: 27 de enero de 2021 tortillas extruidas de maíz azul se seleccionaron sobre las variables de respuesta: ácido linoleico $(A L)$, ácido oleico $(A O)$, campesterol (FC), estigmasterol (FS) y $\beta$-sitosterol ( $\beta F S)$, los modelos cuadráticos de predicción fueron adecuados y reproducibles dentro de la matriz de factores de proceso. Empleando función de deseabilidad, condiciones óptimas de cocción-alcalina por extrusión para el desarrollo de tortillas de maíz azul corresponden a TE $\left(119^{\circ} \mathrm{C}\right)$, VT (79 rpm) y deseabilidad global $(D=0.906)$. Los valores de las variables obtenidas de modelos predictivos fueron comparados con pruebas experimentales con estrecha concordancia entre ambos valores. Por lo tanto, MSR es recomendable para la optimización, particularmente en combinación con otros procedimientos.

Palabras clave: maíz nativo, extrusión cocción alcalina, optimización, función de deseabilidad, metodología de superficie de respuesta.

\section{INTRODUCTION}

The making of table tortillas is established on the nixtamalization process, based on lime cooking of whole maize grains (Serna-Saldivar and Chuck-Hernandez, 2019). Nevertheless, this traditional process has several disadvantages, such as high-energy requirement, and abundant water consumption discarded as high alkaline effluent with a high soluble and suspended solids concentration. These wastewater solids, called nejayote, contain some nutrients associated with the maize pericarp tissue, lost during this alkaline treatment (Cuevas-Rodríguez et al., 2009; Gutiérrez-Uribe et al., 2010). Therefore, alternative processes to overcome disadvantages of the nixtamalization process are needed, especially in more environmental-friendly maize processing methods. The lime-cooking extrusion process has been studied with a technological alternative to make dough flours applicable to developing table tortillas with comparable attributes as those elaborated employing conventional processes (Milán-Carrillo et al., 2006). These emerging technologies offer benefits such as energy-saving, null generation of wastewater production, and better-quality control (Cuevas- 
Rodríguez et al., 2009). Hence, the nutrients and bioactive compounds associated with the outermost layers of maize are preserved, and the developing foodstuffs are similar to whole grain (Serna-Saldivar and Chuck-Hernandez, 2019).

Mexican native pigmented maize and its products have gained prominence due to a relevant source of diverse phytochemicals such as phenolics, carotenoids, dietary fiber, triglycerides, and phytosterols (Acosta-Estrada et al., 2014; Corrales-Bañuelos et al., 2016; López-Martínez et al., 2009; Mora-Rochín et al., 2016). Most of these bioactive compounds exert antioxidant effects preventing oxidative stress related to chronic diseases and cancer (Reynoso-Camacho et al., 2015; Urias-Lugo et al., 2015). The current interest has been expressed concerning the health benefits of consuming phospholipids and phytosterols. These phytochemicals inhibit the absorption of cholesterol from the small intestine, thus effectively lowering total blood cholesterol and lowdensity lipoprotein (LDL), a potential risk factor for cardiovascular diseases (Barrera-Arellano et al., 2019).

Fatty acids and phytosterols are unstable at high temperatures and, being unsaturated lipophilic compounds, are susceptible to oxidation. However, phytosterols are considered more stable than mono-unsaturated fatty acids (e.g., oleic acid) because of the steric hindrance in the ring structure. The extrusion process can prevent the release and oxidation of fatty acid by denaturing hydrolytic enzymes; on the other hand, phytosterols content can increase with a 90 to $110{ }^{\circ} \mathrm{C}$ extrusion temperature (Camire et al., 1990; Hu et al., 2018; Tolve et al., 2020). However, little has been reported about maize extrusion process conditions'to prevent a decreased in these compounds.

Response surface methodology (RSM) is a collection of techniques used in empirical studies to determine the relationship between a response variable and several input variables. It is a useful mathematical statistics method for establishing models evaluating the relative significance of variables and determining optimal conditions of desirable responses (Khuri and Cornell, 1987). Desirability optimization (DOM) is an analytical technique for optimizing multiple response variables employing mathematical transformations, developed by Harrington (1965), and later modified and extended by Derringer and Suich (1980). Some authors have reported that the extrusion cooking process could be resolved using RSM and DOM (Escalante-Aburto et al., 2014; Ramos-Enriquez et al., 2018; Ortiz-Cruz et al., 2020). Therefore, it could be used to optimize process conditions that lead to minimal changes (or maximization) in flours and tortillas lipophilic compounds, considering that no studies have been reported on fatty acids and phytosterols throughout the different steps of maize tortilla processing. Thus, this study's purpose was to use RSM and DOM to optimize lime cooking extrusion conditions from mexican native blue maize, that would maximize lipophilic compounds to obtain a highquality flour to make tortillas.

\section{MATERIALS AND METHODS Material}

The study was performed on blue maize kernels from the Elotero Sinaloa landrace of Mexico's northwestern region. These pigmented maize accessions were collected during 2018 from open-pollinated maintained by traditional farmers at their villages in the municipality of Concordia located at $\left(23^{\circ} 17^{\prime} 18^{\prime \prime} \mathrm{N}, 106^{\circ} 4^{\prime} 3^{\prime \prime} \mathrm{W}\right)$, in the state of Sinaloa México. Maize samples were stored at $-4^{\circ} \mathrm{C}$ until use.

\section{Production of extruded maize flour}

The extrusion cooking experiments of pigmented maize grits (moisture content of $28 \%$ ) were carried out on a single screw laboratory extruder Model 20 DN (CW Brabender Instruments, Inc., NJ, USA), with a length-to-diameter rate of 20:1, an internal diameter of $19 \mathrm{~mm}$, nominal compression ratio 1:1 and die opening of $2.4 \mathrm{~mm}$. A screw-operated feed hopper-fed the extruders at $30 \mathrm{rpm}$. The extruder feed was manual at $70 \mathrm{~g} / \mathrm{min}$. Extrusion temperature (ET) was defined as the temperature at the die end of the barrel. Table 1 shows the combinations of extrusion temperature (ET) and screw speed (SS) used for producing tortillas from extruded pigmented maize flours. Extrudates were cooled and dried, using ambient conditions $\left(25^{\circ} \mathrm{C}, \mathrm{RH}=65 \%\right)$, for one day and milled (UD Cyclone Sample Mill, UD Corp, Boulder, CO, USA) to pass through an $80-U S$ mesh $(0.180 \mathrm{~mm})$ screen, packed in plastic bags, and stored at $4{ }^{\circ} \mathrm{C}$.

\section{Tortilla preparation from extruded maize flours}

Tortillas were made by mixing $200 \mathrm{~g}$ of extruded maize flours with $200 \mathrm{~mL}$ of water to achieve an adequate masa consistency to produce table tortillas. According to Cuevas-Rodríguez et al. (2009), the fresh dough was divided into $30 \mathrm{~g}$ pieces and flattened using a manual machine. The resulting disks were baked on a hot griddle at $220 \pm 5^{\circ} \mathrm{C}$ for $10 \mathrm{~s}$ on each side, until the puffing of the tortilla occurred. The fresh tortillas were dried and milled to pass through an 80 -US mesh $(0.180 \mathrm{~mm})$ sieve and packed in plastic bags. Tortillas made by lime extrusion cooking flours were stored at $-20^{\circ} \mathrm{C}$ until use.

\section{Lipid extraction}

Lipids were extracted by mixing $4 \mathrm{~g}$ of maize samples with $\mathrm{n}$-hexane/dichloromethane $(40 \mathrm{~mL}, 1: 1, \mathrm{v} / \mathrm{v})$ under stirring conditions for $1 \mathrm{~h}$ at room temperature as previously described (Esche et al., 2012).

\section{Lipophilic biocompounds identification and quantifica- tion}

The identification and quantification of lipophilic biocompounds were performed in a HPLC-ELSD-UV (Model G1969A Agilent 1100 Santa Clara, CA, USA) as previously reported (Chávez-Santoscoy et al., 2014). The separation was performed in a Luna C8 $(250 \mathrm{~mm} \times 4.6 \mathrm{~mm}, 5 \mu \mathrm{m}$; Phenomenex, Torrance, $C A$, USA) column, set at $40^{\circ} \mathrm{C}$, and an injection volume of $20 \mu \mathrm{L}$. The mobile phase consisted of acetonitrile 
Table 1. Experimental design ${ }^{1}$ used to obtain combinations of lime cooking extrusion variables for extruded maize flours production from native blue maize and experimental results for response variables.

Tabla 1. Diseño experimental utilizado para obtener la combinación de variables del proceso de extrusión cocción alcalina empleadas para la producción de harinas de maíz extrudidas a partir de maíz azul nativo y resultados experimentales de las variables de respuesta.

\begin{tabular}{|c|c|c|c|c|c|c|c|}
\hline \multirow{3}{*}{ Assay $^{2}$} & \multirow{3}{*}{$\begin{array}{c}\begin{array}{c}\text { Process } \\
\text { variables }^{3}\end{array} \\
{\left[E T,\left(X_{1}\right)\right]}\end{array}$} & & \multicolumn{5}{|c|}{ Response variables ${ }^{4}$} \\
\hline & & \multicolumn{2}{|c|}{ Fatty acids } & \multicolumn{3}{|c|}{ Phytosterols } & \multirow[b]{2}{*}{$\begin{array}{c}\beta \text {-sitosterol ( } \beta S P) \\
Y_{\beta S F} \\
\end{array}$} \\
\hline & & {$[S S,(X 2)]$} & $\begin{array}{c}\text { Linoleic Acid (LA) } \\
Y_{\text {LA }} \\
\end{array}$ & $\begin{array}{c}\text { Oleic Acid (OA) } \\
\mathrm{Y}_{\mathrm{OA}} \\
\end{array}$ & $\begin{array}{c}\text { Campesterol (CP) } \\
\mathrm{Y}_{\mathrm{CF}} \\
\end{array}$ & $\begin{array}{c}\text { Stigmasterol (SP) } \\
\mathbf{Y}_{\mathrm{SF}} \\
\end{array}$ & \\
\hline 1 & $65(-1)$ & $78(-1)$ & $2,127.0$ & $1,098.9$ & $3,257.3$ & $2,392.9$ & $20,393.5$ \\
\hline 2 & $135(+1)$ & $78(-1)$ & $2,883.6$ & $1,556.5$ & $4,353.9$ & $3,108.7$ & $22,465.1$ \\
\hline 3 & $65(-1)$ & $212(+1)$ & $2,139.5$ & 868.6 & $3,157.2$ & $2,990.2$ & $17,945.3$ \\
\hline 4 & $135(+1)$ & $212(+1)$ & $2,193.2$ & $1,092.6$ & $2,578.6$ & $2,855.4$ & $16,504.7$ \\
\hline 5 & $51(-1.414)$ & $145(0)$ & $2,362.2$ & 945.0 & $3,193.6$ & $2,374.0$ & $15,465.7$ \\
\hline 6 & $150(+1-414)$ & $145(0)$ & $3,005.8$ & $1,130.9$ & $3,824.6$ & $2,631.2$ & $18,222.6$ \\
\hline 7 & $100(0)$ & $50(-1.414)$ & $3,020.9$ & $1,480.1$ & $4,839.9$ & $3,208.3$ & $24,447.6$ \\
\hline 8 & $100(0)$ & $240(+1.414)$ & $2,123.7$ & $1,161.2$ & $3,268.1$ & $2,954.7$ & $18,471.1$ \\
\hline 9 & $100(0)$ & $145(0)$ & $3,066.3$ & $1,491.9$ & $3,627.8$ & $3,299.5$ & $20,211.4$ \\
\hline 10 & $100(0)$ & $145(0)$ & $3,198.3$ & $1,492.2$ & $3,832.2$ & $3,292.9$ & $19,991.4$ \\
\hline 11 & $100(0)$ & $145(0)$ & $3,190.4$ & $1,512.3$ & $3,775.9$ & $3,408.9$ & $21,224.1$ \\
\hline 12 & $100(0)$ & $145(0)$ & $3,295.6$ & $1,462.1$ & $3,007.6$ & $3,170.9$ & $19,789.1$ \\
\hline 13 & $100(0)$ & $145(0)$ & $3,025.6$ & $1,578.3$ & $2,990.2$ & $3,154.7$ & $20,849.4$ \\
\hline
\end{tabular}

${ }^{1}$ Central composite design with two factors and five levels; 13 assays. ${ }^{2}$ Does not correspond to order of experiments. ${ }^{3} \mathrm{ET}=\mathrm{Extruded}$ temperature ( $\left.{ }^{\circ} \mathrm{C}\right), \mathrm{SS}=$ Screw speed (rpm); values in parentheses are coded levels. ${ }^{4} \mathrm{LA}=$ Linoleic acid ( $\left.\mu \mathrm{g} / 100 \mathrm{~g} \mathrm{DW}\right), \mathrm{OA}=\mathrm{Oleic}$ acid $(\mu \mathrm{g} / 100 \mathrm{~g} \mathrm{DW}), \mathrm{CP}=\mathrm{Campesterol}(\mu \mathrm{g} / 100 \mathrm{~g}$ $\mathrm{DW}), \mathrm{SP}=$ Stigmasterol $(\mu \mathrm{g} / 100 \mathrm{~g} \mathrm{DW}), \beta \mathrm{SP}=\beta$-sitosterol $(\mu \mathrm{g} / 100 \mathrm{~g} \mathrm{DW})$.

(A) and 55\% methanol, with 1\% formic acid in water (solvent B). The gradient elution was: $0-7 \mathrm{~min} 0 \% \mathrm{~B}$ (flow rate $0.6 \mathrm{~mL}$ / $\mathrm{min}$ ), 7-15 $\mathrm{min}$ 0-15\% $\mathrm{B}$ (flow rate $0.6-1.2 \mathrm{~mL} / \mathrm{min}$ ), $15-20 \mathrm{~min}$ $15-80 \% \mathrm{~B}$ (flow rate $1.2-1.5 \mathrm{~mL} / \mathrm{min}$ ) and $20-50 \mathrm{~min} 80-100 \%$ (flow rate $1.5 \mathrm{~mL} / \mathrm{min}$ ). The quantification was compared with linoleic and oleic acids, $\beta$-sitosterol, campesterol, and stigmasterol standards (Sigma-Aldrich Co). Results expressed in $\mu \mathrm{g}$ of fatty acids or phytosterols/100 $\mathrm{g}$ of dry sample.

\section{Regression analysis and optimization}

In this research, the RSM was used to determine the optimal experimental lime cooking extrusion process conditions (extrusion temperature and speed screw) to obtain extruded flour from mexican blue maize. The optimal response variables: fatty acids [linoleic (LA) and oleic (OA) acids], and phytosterols [campesterol (CP), stigmasterol (SP) and $\beta$-sitosterol $(\beta S P)]$, in a central composite design (CCD) with two control variables, extruded temperature (ET) and speed screw (SS) were used. Maximum and minimum values were chosen according to previous data from preliminary trials. Table 1 shows the experimental design and the response data of tortillas made with extruded blue maize flours. The quadratic model applied to predict the response variables is given below.

$$
Y=\beta_{O}+\sum_{i=1}^{2} \beta_{i} X_{i}+\sum_{i=2}^{2} \beta_{i i} X_{i}^{2}+\sum_{i=1}^{2} \sum_{i=j+1}^{2} \beta_{i j} X_{i} X_{j}+\epsilon
$$

Data were subjected to the stepwise regression analysis; the significant terms $(P<0.05)$ were used to fit the predictive model for each response variable (Khuri and Cornell, 1987). According to the software program, multiple response optimization was implemented throughout the desirability function (Derringer and Suich, 1980). To establish the desirability of several arrangements of the experimental process variables (ET and SS) were set as "in the range", whereas that of response variables ( $L A, O A, C P, S P$, and $\beta S P$ ) was a goal set to obtain maximum, and the desirability value was calculated. The arrangement of experimental factors yielding the uppermost desirability was nominated as the optimal lime extrusion cooking condition.

\section{RESULTS AND DISCUSSION}

\section{Appropriate models by response variables}

The quadratic polynomial equations for each response variable ( $L A, O A, C P, S P$, and $\beta S P$ ), efficiently fitted to the experimental values of lime extrusion cooking conditions (ET and SS) using multiple regression analysis, are shown in Table 1. The regression coefficients and analysis of variance of the quadratic models, showing the relationships among response variables and process variables for tortillas produced from extruded blue maize, are shown in Table 2. According to Vera-Candioti et al. (2014), a good predictive model should have the following statistical parameters: coefficient of determination $\left(R^{2}\right)$ and adjusted- $R^{2}$ high (>0.80), very small P-value $(<0.05)$, coefficient of variation $(C V<10 \%)$, lack 
Table 2. The regression analysis of second order polynomial models for each of the response variables studied Tabla 2. Análisis de regresión de modelos polinomiales de segundo orden para cada una de las variables de respuestas estudiadas.

\begin{tabular}{|c|c|c|c|c|c|}
\hline \multirow{4}{*}{ Parameter } & \multicolumn{5}{|c|}{ Regression parameter coefficients } \\
\hline & \multicolumn{2}{|l|}{ Fatty acids } & \multicolumn{3}{|l|}{ Phytosterols } \\
\hline & Linoleic (LA) & Oleic (OA) & Campesterol (CP) & Stigmasterol (SP) & $\beta$-Sitosterol ( $\beta S P$ ) \\
\hline & Coded values & Coded values & Coded values & Coded values & Coded values \\
\hline \multicolumn{6}{|l|}{ Intercept } \\
\hline$\beta_{0}$ & $3,155.2$ & $1,495.4$ & $3,743.3$ & $3,285.3$ & $20,393.1$ \\
\hline Linear & & & & & $566.2^{* *}$ \\
\hline$\beta_{1}$ & $215.1^{* *}$ & $119.2^{* *}$ & $213.8^{* *}$ & $118.1^{* *}$ & $-2,107.6^{* *}$ \\
\hline$\beta 2$ & $-243.3^{* *}$ & $-144.3^{* *}$ & $-549.8^{* *}$ & $-1.8^{\mathrm{NS}}$ & \\
\hline \multicolumn{6}{|l|}{ Quadratic } \\
\hline & $-308.7^{* *}$ & $235.6^{* *}$ & $-209.6^{* *}$ & $-380.2^{* *}$ & $-1,740.6^{* *}$ \\
\hline$\beta 22$ & $-364.6^{* *}$ & $-94.2^{* *}$ & $62.9^{\mathrm{NS}}$ & $-90.7^{\mathrm{NS}}$ & $567.0^{\mathrm{NS}}$ \\
\hline \multicolumn{6}{|l|}{ Interactive } \\
\hline$\beta_{12}$ & $-175.7^{\mathrm{NS}}$ & $-56.2^{\mathrm{NS}}$ & $-493.8^{* *}$ & $-212.7^{* *}$ & $-878.1^{* *}$ \\
\hline Model F-values & 12.62 & 22.19 & 16.36 & 14.24 & 32.75 \\
\hline$p$-value & 0.002 & 0,0004 & 0.001 & 0.002 & 0.0001 \\
\hline $\mathrm{R}^{2}$ & 0.900 & 0.941 & 0.921 & 0.911 & 0.959 \\
\hline$R_{\text {ajust }}^{2}$ & 0.829 & 0.898 & 0.865 & 0.847 & 0.825 \\
\hline Lack of Fit & $0.06^{\mathrm{NS}}$ & $0.123^{\mathrm{NS}}$ & $0.085^{\mathrm{NS}}$ & $0.31^{\mathrm{NS}}$ & $0.36^{\mathrm{NS}}$ \\
\hline CV & 7.1 & 6.2 & 6,2 & 4.5 & 3.2 \\
\hline Ade Pre & 8.15 & 12.1 & 13.7 & 10.1 & 19.4 \\
\hline
\end{tabular}

NS = Not significant $(p>0.05) ; * *$ Significant $(p<0.05)$

of fit test $(P>0.05)$, and adequate precision $>4$. The models were adequate for predicting the five response variables at different lime extrusion cooking conditions based on these criteria. In this study, the results reveal that the regression response models could depict the experimental region's responses (Table 2 ).

\section{Response surface model for linoleic acids}

The regression analysis showed that Linoleic acid (LA) was significantly dependent on linear terms of extruded temperature (ET) and screw speed (SS), and quadratic terms $\left[(E T)^{2},(S S)^{2}\right]$ (Table 2). The following equation can be described as the predicted model for LA in terms of coded values:

$$
\mathrm{Y}_{\mathrm{LA}}=3,155.2+215.1 X_{1}-243.3 X_{2}-308.7 X_{1}^{2}-364.6 X_{2}^{2}
$$

The response regression model exhibitions, show lower $(P<0.002)$ and $C V=7.1 \%$ values, a satisfactory level by the correlation coefficients $\left(R^{2}=0.900 ; R^{2}\right.$ adjust $\left.=0.829\right)$, lack of fit $(P>0.06)$, and PRESS $>8.2$ (Table 2). These statistical parameters demonstrated that the fitted model was suitable and reproducible. The surface response plots are revealed in Fig. 1A. The highest amounts of LA $(3,280.9 \mu \mathrm{g} / 100 \mathrm{~g} \mathrm{DM})$ were observed at ET $=115-120^{\circ} \mathrm{C} / \mathrm{SS}=110-120 \mathrm{rpm}$.

\section{Response surface model for oleic acid}

The oleic acid $(\mathrm{OA})$ content in the blue maize tortillas prepared from extruded flours was dependent on linear terms ET, SS, and quadratic terms $\left[(E T)^{2},(\mathrm{SS})^{2}\right]$ (Table 2), the following regression equation confirmed the estimate of the effects of independent variables on OA:

$\mathrm{Y}_{\mathrm{OA}}=1,495.4+119.2 X_{1}-144.3 X_{2}-235.6 X_{1}^{2}-94.2 X_{2}^{2}$

The response regression model displays the lower $(\mathrm{P}<0.0004)$ and $\mathrm{CV}=6.2 \%$, PRESS $>12.1$, and coefficient of correlation $\left(R^{2}\right)$ from the developed model, which described $94.1 \%$ of the total variability to OA on extruded blue maize tortillas, suggesting the selected model adequately illustrates the information for this response. Response surface contours for $\mathrm{OA}$ as functions of the independent process variables are represented in Fig. 1B. The maximum (1,561.3 $\mu \mathrm{g} / 100 \mathrm{~g} \mathrm{DM})$ values of $\mathrm{OA}$ were observed at $\mathrm{ET}=110-120^{\circ} \mathrm{C} / \mathrm{SS}=78-85$ rpm.

The behavior of fatty acids as a function of the lime cooking extrusion variables is shown in the surface graphs of Fig $1 \mathrm{~A}$ and Fig 1B. In general, LA and OA's desirable values in tortillas made with extruded flours were observed in the ET range $\left(100-125^{\circ} \mathrm{C}\right)$ values and lowest SS values. Some research indicated that during cooking extrusion, the only processing variable that had a significant effect on the fat loss was temperature profile. Its increase caused an augment of fat loss, which could be attributed to forming a bond between starch and lipid fraction. Moreover, the highest barrel temperature values favor the migration of fat fraction outside from mass extruded (De Pilli et al., 2011). 

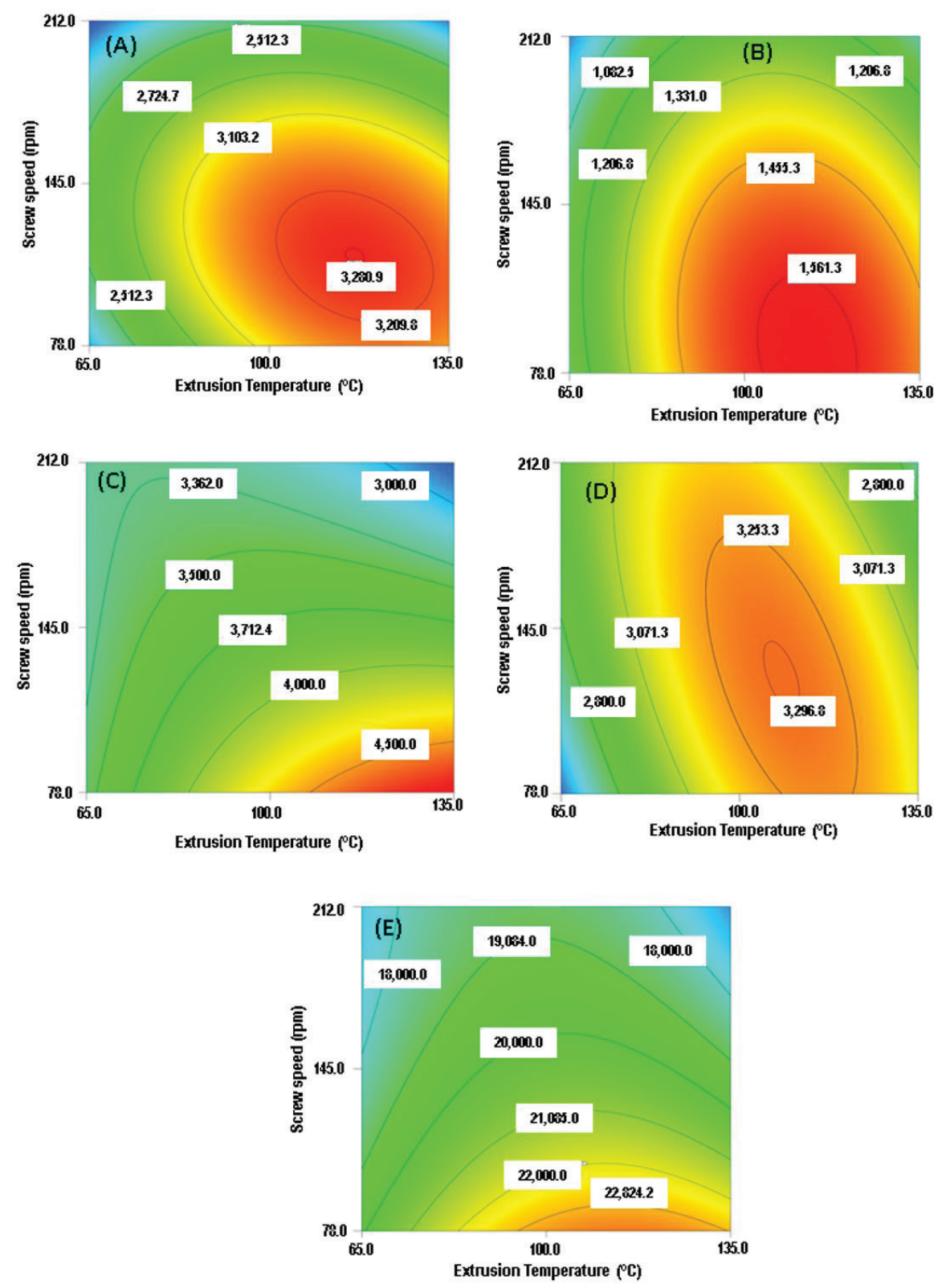

Fig. 1 Contour plots showing the effect of the lime cooking extrusion condition (ET and SS) on the response variables (A) Linoleic acid (LA), (B) Oleic acid (OA), (C) Campesterol (CP), (D) Stigmasterol (SP), and (E) $\beta$-sitosterol ( $\beta S P$ ) of extruded blue maize tortillas.

Fig. 1 Gráficos de contorno mostrando el efecto de las condiciones de extrusión cocción alcalina (TE and VT) sobre las variables de respuesta (A) Ácido linoleico (LA), (B) Ácido oleico (OA), (C) Campesterol $(C P),(D)$ Estigmasterol (SP) y (E) $\beta$-sitosterol ( $\beta S P$ ) de tortillas de maíz azul extruidas.

\section{Response surface model for campesterol}

Changes in campesterol (CP) of tortillas prepared with extruded blue maize flours were affected by $\mathrm{ET}, \mathrm{SS}$, the quadratic term (ET) ${ }^{2}$, and interaction (ET)(SS) (Table 2); the following regression equation was used to estimate of the effects of independent variables on CP using coded variables.

$$
\mathrm{Y}_{\mathrm{CP}}=3,743.3+213.8 X_{1}-549.8 X_{2}-209.6 X_{1}^{2}-493.8 X_{1} X_{2}
$$

The predictive model explained $92.1 \%$ of the total variability $(\mathrm{P}<0.001)$ in $\mathrm{CP}$ values (Table 2$)$. The response sur- face contour plot for $\mathrm{CP}$ as a function of the lime extrusion cooking process variables is shown in Fig. $1 \mathrm{C}$. The maximum $(4,500.0 \mu \mathrm{g} / 100 \mathrm{~g} \mathrm{DM})$ value of $\mathrm{CP}$ were observed at $\mathrm{ET}=$ $120-135^{\circ} \mathrm{C} / \mathrm{SS}=78-85^{\circ} \mathrm{C}$.

\section{Response surface model for stigmasterol}

The stigmasterol (SP) of tortillas prepared from extruded native pigmented maize flours were influenced significantly by linear terms of ET, the quadratic term (ET)2, and interaction (ET)(SS) (Table 2). The regression equation relating the response function SP, measured as independent 
variables, was given in terms of uncoded variables by the following equation:

$$
Y_{S P}=3,284.3+118.1 X_{1}-380.2 X_{1}^{2}-217.7 X_{1} X_{2}
$$

The significance $(P<0.002)$ of the developed model for $\mathrm{SP}$ is given in Table 2. The lack of fit ( $P \geq 0.05), C V$, and PRESS had satisfactory levels, indicating that the experimental data were satisfactorily explained in a $91.1 \%$. The response surface contour plot for SP is shown in Fig. 1D. The maximum SP $(3,296.3 \mu \mathrm{g} / 100 \mathrm{~g} \mathrm{DM})$ value was observed at ET $=105-128$ ${ }^{\circ} \mathrm{C} / \mathrm{SS}=78-85 \mathrm{rpm}$.

\section{Response surface model for $\beta$-Sitosterol}

The regression analysis showed in linear terms (ET and SS), quadratic terms (ET) ${ }^{2}$, and interaction (ET)(SS), a significant effect on $\beta$-Sitosterol ( $\beta S P$ ) of extruded blue maize tortillas (Table 2 ). The following equation can describe the predicted model for $\beta$ SP in terms of coded values:

$$
Y_{\beta S P}=20,393.1+566.2 X_{1}-2,107.6 X_{2}-1,740.6 X_{1}^{2}-878.1 X_{1} X_{2}
$$

The predictive model explained $95.9 \%$ of the total variability $(P \leq 0.0001)$ in $\beta S P$ values (Table 2$)$. The response surface contour plot for $\beta S P$ is shown in Fig. 1E. Increases in extrusion temperature result in increases in $\beta S P$ content, reaching a maximum $(22,824.2 \mu \mathrm{g} / 100 \mathrm{~g} \mathrm{DM})$ at 100 to 135 ${ }^{\circ} \mathrm{C}$ ET and SS $=79$ to $90 \mathrm{rpm}$. The remaining $C P, \mathrm{SP}$, and $\beta S P$ amounts in tortillas from extruded mexican blue maize varied from 25.8 to $48.4,23.7$ to 34.1 , and 139.5 to $244.5 \mu \mathrm{g} / 100$ $\mathrm{g}$, respectively (Table 1 ). Our results showed that phytosterol levels tested in the present study were within the range of 25 varieties of raw maize reported by Esche et al. (2013). Overall, these significant losses of pigmented maize samples' phytosterols during the tortillas elaboration could be attributed to the higher temperature during processing, facilitating thermo-oxidative degradation of phytosterols, including oxidized phytosterols, fragmented phytosterol molecules, volatile compounds, and oligomers (Rudzinska et al., 2009).

\section{Optimization and validation of extrusion conditions}

Fig. 2 exhibited the desirability functions response surface to attain optimum conditions in optimized tortillas made with extruded mexican blue maize. By applying the desirability function method, the optimum lime extrusion cooking conditions for the development of extruded native blue maize tortillas correspond to extrusion temperature (ET, $119^{\circ} \mathrm{C}$ ) and screw speed (SS, $79 \mathrm{rpm}$ ) with global desirability value $(D=0.906)$.

The fitness of the established model for the estimate was confirmed by relating the estimated and experimental values. The optimum condition (ET $=119^{\circ} \mathrm{C}$ and SS $=78$ rpm) was experimentally tested to confirm the accuracy of the model equations, using the average values obtained in LA and OA experiments. CP, SP, and $\beta S P$ under these optimal conditions were 3,019.9, 1,625.6, 4,484.9, 3,101.8, and $22,152.9 \mu \mathrm{g} / 100 \mathrm{~g} \mathrm{DW}$, respectively, which was in agreement with the predicted information (Table 3 ). The experimental results denote the correctness of the established quadratic models. It is noteworthy to mention that these best values are acceptable inside the specified array of process factors.
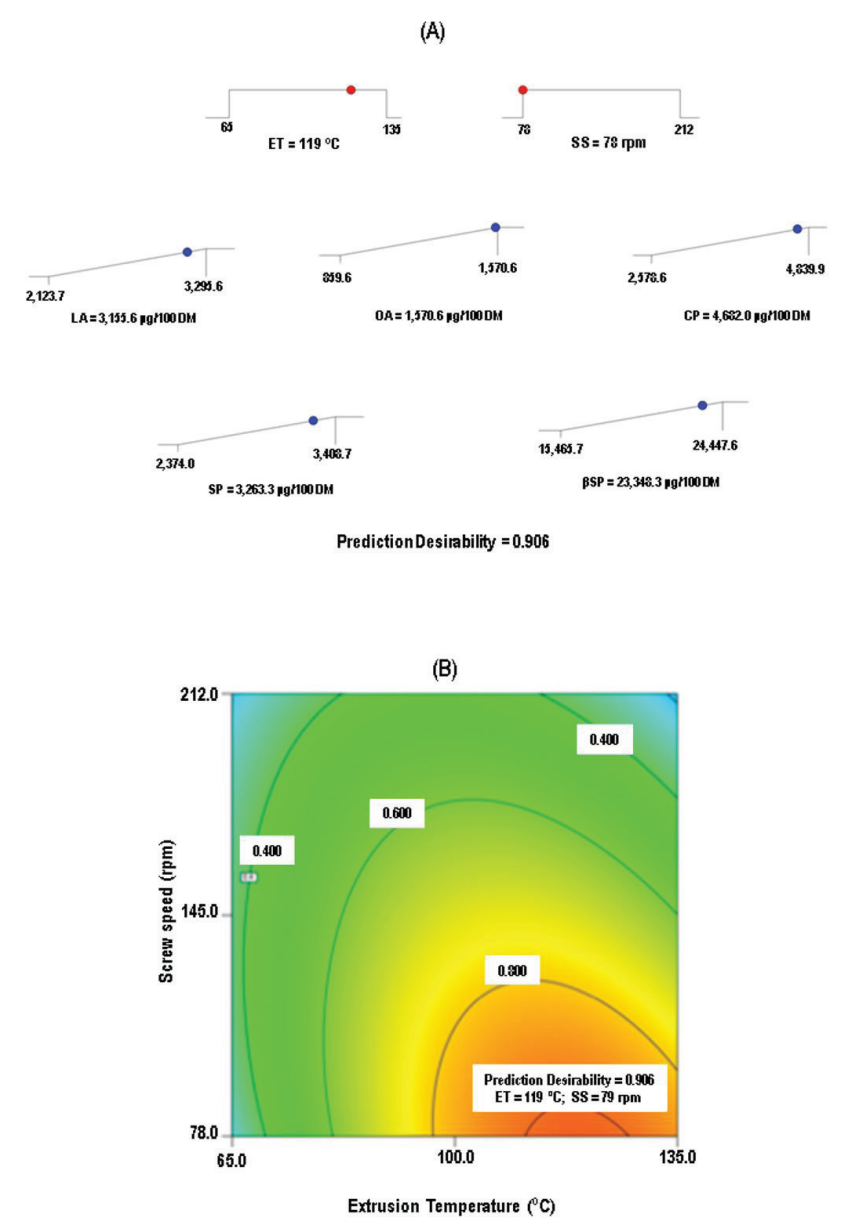

Fig. 2 Desirability analysis. (A) plots ramp showing the optimal experimental parameters (ET and SS) that maximize LA, OA, CP, SP and $\beta S P$, (B) Contour plot of overall desirability showing the best combination of lime cooking extrusion condition (ET and SS) for producing optimized extruded blue maize tortillas.

Fig. 2 Análisis de deseabilidad. (A) gráficos de parámetros experimentales óptimos (TE and SS) que maximizan AL, AO, PC, PS y $\beta$ PS, (B) Gráfico de contorno de deseabilidad global mostrando la mejor combinación de condiciones de extrusión cocción alcalina (TE y VT) para elaborar tortillas de maíz azul extruidas optimizada.

Table 3. Comparison of predicted and experimental values for each response variables.

Tabla 3. Comparación de valores de predicción y experimentales para cada variable de respuesta.

\begin{tabular}{lccc}
\hline $\begin{array}{l}\text { Response } \\
\text { variables }^{\text {a }}\end{array}$ & \begin{tabular}{c} 
Predicted $_{\text {values }^{\mathbf{b}}}$ \\
\hline Linoleic acid (LA)
\end{tabular} & $\begin{array}{c}\text { Experimental } \\
\text { values }^{\mathbf{c}}\end{array}$ & $\begin{array}{c}\text { Percent relative } \\
\text { error }^{\mathbf{d}}\end{array}$ \\
Oleic acid (OA) & $1,570.6$ & $3,019.9 \pm 184.2$ & 4.30 \\
Campesterol (CP) & $4,682.0$ & $1,625.6 \pm 87.8$ & 3.50 \\
Stigmasterol (SP) & $3,263.3$ & $3,104.9 \pm 331.9$ & 4.21 \\
$\beta$-sitosterol ( $\beta$ SP) & $23,348.3$ & $22,152.9 \pm 1,572.8$ & 4.95 \\
\hline
\end{tabular}

${ }^{\mathrm{a}} \mu \mathrm{g} / 100 \mathrm{~g} \mathrm{DW}$

bPredicted using response surface, quadratic model.

'Mean \pm standard deviation of triplicate determinations from experiments.

d Percent error (percentage error) is the difference between an experimental and predicted value, divided by the predicted value, multiplied by 100 to give a percent. 


\section{CONCLUSIONS}

Mexican pigmented maize used in this study was suitable for tortillas preparation throughout the lime cooking extrusion process. RSM and DOM were useful in producing predictive models and establishing relationships between processing factors and key responses for tortillas production from blue maize landrace. The optimum combination of lime extrusion cooking process variables, to produce optimized tortillas from extruded native blue maize, correspond to extrusion temperature of $119^{\circ} \mathrm{C}$ and screw velocity of $79 \mathrm{rpm}$. Additional studies are needed to determine the nutraceutical potential of tortillas using optimized extruded blue maize landrace.

\section{ACKNOWLEDGMENTS}

This research was supported by grants from Consejo Nacional de Ciencia y Tecnología (CONACyT-México, Project 168279) and Programa de Mejoramiento al Profesorado (PROMEP-México, Project 103.5/12/3360).

\section{REFERENCES}

Acosta-Estrada, B.A., Gutierrez-Uribe, J.A. and Serna-Saldivar, S.O. 2014. Bound phenolics in food, a review. Food Chemistry, 152(1):46-55. https://doi.org/10.1016/j. foodchem.2013.11.093

Barrera-Arellano, D., Badan-Ribeiro, A.P. and Serna-Saldivar, S.O. 2019. Corn Oil: Composition, Processing and Utilization. In Corn Chemistry and Technology (3 $3^{\text {rd }}$ ed., 593-613). ST Paul, MN: AACCI International. https://doi.org/10.1016/B978-012-811971-6.00021-8

Camire, M.E., Camire, A.L. and Krumhar, K. 1990. Chemical and nutritional changes. Critical Reviews in Food Science and Nutrition, 29(1): 35-57. https:doi. org/10.1080/10408399009527513

Chávez-Santoscoy, R.A., Tovar, A.R., Serna-Saldívar, S.O., Torres, N. and Gutiérrez-Uribe, J.A. 2014. Conjugated and free sterols from black bean (Phaseolus vulgaris L.) seed coats as cholesterol micelle disruptors and their effect on lipid metabolism and cholesterol transport in rat primary hepatocytes. Genes and Nutrition, 9(1):367. https://doi. org/10.1007/s12263-013-0367-1

Corrales-Bañuelos, A.B., Cuevas-Rodríguez, E.O., Gutiérrez-Uribe, J.A., Milán-Noris, E.M., Reyes-Moreno, C., Milán-Carrillo, J. and Mora-Rochín, S. 2016. Carotenoid composition and antioxidant activity of tortillas elaborated from pigmented maize landrace by traditional nixtamalization or lime cooking extrusion process. Journal of Cereal Science, 69:6470. https://doi.org/10.1016/j.jcs.2016.02.009

Cuevas-Rodriguez, E.O., Reyes-Moreno, C., Eckhoff, S.R. and Milán-Carrillo, J. 2009. Nixtamalized instant flour from corn (Zea mays L.) meal: optimization of nixtamalization conditions. Cereal Chemistry, 86(1):7-11. https://doi. org/10.1094/CCHEM-86-1-0007

De Pilli, T., Derossi, A., Talja, R.A., Jouppila, K. and Severini, C. 2011. Study of starch-lipid complexes in model system and real food produced using extrusion-cooking technology. Inne Food Science \& Emer Tech. 12(4):610-616.
Derringer, G. and Suich, R. 1980. Simultaneous optimization of several response variables. Journal of Quality Technology, 12:214-219.

Escalante-Aburto, A., Ramírez-Wong, B., Torres-Chávez, P., López-Cervantes, J., Figueroa-Cárdenas, J., Barrón-Hoyos, J. and Gutiérrez-Dorado, R. 2014. Obtaining ready-to-eat blue corn expanded snacks with anthocyanins using an extrusion process and response surface methodology. Molecules 19(12):21066-21084. https://doi:10.3390/ molecules191221066

Esche, R., Barnsteiner, A., Scholz, B. and Engel, K.H. 2012. Simultaneous analysis of free phytosterols/phytostanols and intact phytosteryl/phytostanyl fatty acid and phenolic acid esters in cereals. Journal of Agricultural and Food Chemistry, 60(21):5330-5339. https://doi.org/10.1021/jf300878h

Esche, R., Scholz, B. and Engel, K.H. 2013. Online LC-GC analysis of free sterols/stanols and intact steryl/stanyl esters in cereals. Journal of Agricultural and Food Chemistry, 61(46):1093210939.

Gutiérrez-Uribe, J.A., Rojas-García, C., García-Lara, S. and SernaSaldivar, S.O. 2010. Phytochemical analysis of wastewater (nejayote) obtained after lime-cooking of different types of maize kernels processed into masa for tortillas. Journal of Cereal Science, 52(3):410-416. https://doi.org/10.1016/j. jcs.2010.07.003

Harrington, E.C. 1965. The desirability function. Industrial Quality Control, 21:494-498.

Hu, Z., Tang, X., Zhang, M., Hu, X., Yu, C., Zhu, Z. and Shao, $Y$. 2018. Effects of different extrusion temperatures on extrusion behavior, phenolics acids, antioxidants activity, anthocyanins and phytosterols of black rice. Royal Society of Chemistry Advances, 8: 7123-7132. http://doi.org/10.1039/ c7ra13329d

Khuri, A.L. and Cornell, J.A. 1987. Response surface: Designs and analyses. Marcel Dekker Inc., New York

López-Martínez, L.X., Oliart-Ros, R.M., Valerio-Alfaro, G., Lee, C.H., Parkin, K.L. and Garcia, H.S. 2009. Antioxidant activity, phenolic compounds and anthocyanins content of eighteen strains of Mexican maize. LWT-Food Science and Technology, 42(6):1187-1192. https://doi.org/10.1016/j.lwt.2008.10.010

Milán-Carrillo, J., Gutiérrez-Dorado, R., Perales-Sánchez, J.X., Cuevas-Rodríguez, E.O., Ramírez-Wong, B. and ReyesMoreno, C. 2006. The optimization of the extrusion process when using maize flour with a modified amino acid profile for making tortillas. International Journal of Food Science \& Technology, 41(7):727-736. https://doi.org/10.1111/j.13652621.2005.00997.x

Mora-Rochín, S., Gaxiola-Cuevas, N., Gutiérrez-Uribe, J.A., Milán-Carrillo, J., Milán-Noris, E.M., Reyes-Moreno, C., Serna-Saldivar, S.O. and Cuevas-Rodríguez, E.O. 2016. Effect of traditional nixtamalization on anthocyanin content and profile in Mexican blue maize (Zea mays L.) landraces. LWT- Food Science and Technology, 68:563-569. https://doi. org/10.1016/j.lwt.2016.01.009

Ortiz-Cruz, R.A., Ramírez-Wong, B., Ledesma-Osuna, A.I., TorresChávez, P.I., Sánchez-Machado, D.I., Montaño-Leyva, B., López-Cervantes, J. and Gutiérrez-Dorado, R. 2020. Effect of Extrusion Processing Conditions on the Phenolic Compound Content and Antioxidant Capacity of Sorghum (Sorghum bicolor (L.) Moench) Bran. Plant Foods for Human Nutrition, 75, 252-257. https://doi.org/10.1007/s11130-020-00810-6 
Ramos-Enríquez, J.R., Ramírez-Wong, B., Robles-Sánchez, R.M., Robles-Zepeda, R.E., González-Aguilar, G.A. and Gutiérrez-Dorado, R. 2018. Effect of extrusion conditions and the optimization of phenolic compound content and antioxidant activity of wheat bran using response surface methodology. Plant Foods for Human Nutrition, 73(3): 228234. https://doi:10.1007/s11130-018-0679-9

Reynoso-Camacho, R., Guerrero-Villanueva, G., Figueroa, J.D., Gallegos-Corona, M.A., Mendoza, S., Loarca-Piña, G. and Ramos-Gomez, M. 2015. Anticarcinogenic effect of corn tortilla against 1, 2-Dimethylhydrazine (DMH)-induced colon carcinogenesis in sprague-dawley rats. Plant Food for Human Nutrition, 70:146-152. https://doi.org/10.1007/ s11130-015-0471-z

Rudzińska, M. and Przybylski, R. 2009. Products formed during thermo-oxidative degradation of phytosterols. Journal of the American Oil Chemists' Society, 86(7):651-662.

Serna-Saldivar, S.O. and Chuck-Hernandez, C. 2019. Food uses of lime-cooked corn with emphasis in tortillas and snacks. In Corn, Chemistry and Technology (3rd ed., 469-500). ST Paul,
MN: AACCI International. https://doi.org/10.1016/B978-012-811971-6.00017-6

Tolve, R., Cela, N., Condelli, N., Di Cairano, M., Caruso, M.C. and Galgano, F. 2020. Microencapsulation as a tool for the formulation of functional foods: the phytosterols' case study. Foods, 9(4):470-489. https://doi.org/10.3390/foods9040470

Urias-Lugo, D.A., Heredia, J.D., Muy-Rangel, M.D., Valdez-Torres, J.B., Serna-Saldivar, S.O. and Gutiérrez-Uribe, J.A. 2015. Anthocyanins and phenolic acids of hybrid and native blue maize (Zea mays L.) extracts and their antiproliferative activity in mammary (MCF7), Liver (HepG2), Colon (Caco 2 and HT29) and prostate (PC3) cancer cells. Plant Food for Human Nutrition, 70(2):193-199. https://doi.org/10.1007/ s11130-015-0479-4

Vera-Candioti, L., De Zan, M.M., Cámara, M.S. and Goicoechea, H.C. 2014. Experimental design and multiple response optimization. Using the desirability function in analytical methods development. Talanta, 124:123-138. https:// doi:10.1016/j.talanta.2014.01.034 